\title{
Mag deur taal in 1 Johannes
}

\author{
Author: \\ Jan G. van der Watt ${ }^{1,2}$ \\ Affiliations: \\ ${ }^{1}$ Department of New \\ Testament Exegesis and \\ Source Texts of Christianity, \\ Radboud University, The \\ Netherlands \\ ${ }^{2}$ Faculty of Theology, North- \\ West University, South Africa \\ Note: \\ Prof. Jan van der Watt is a \\ research associate at the \\ Faculty of Theology, North- \\ West University, South Africa. \\ Correspondence to: \\ Jan van der Watt \\ Email: \\ janvanderwatt@kpnmail.nl \\ Postal address: \\ Paterserf 7, 6584GA \\ Molenhoek, The Netherlands \\ Dates: \\ Received: 16 Nov. 2011 \\ Accepted: 19 Dec. 2011 \\ Published: 05 June 2012 \\ How to cite this article: \\ Van der Watt, J.G., 2012, \\ 'Mag deur taal in 1 \\ Johannes', HTS Teologiese \\ Studies/Theological Studies \\ 68(1), \#Art. 1196, 8 pages. \\ http://dx.doi.org/10.4102/ \\ hts.v68i1.1196
}

(C) 2012. The Authors.

Licensee: AOSIS

OpenJournals. This work

is licensed under the

Creative Commons

Attribution License.
Power through language in $\mathbf{1}$ John. Power is often exercised through language. Here it is argued that the author of John utilises different language strategies in order to exert power over and to influence his intended readers. His authority lies in his association with the ethos of the group which he feels he represents. From this position he makes his assumptions and builds his arguments. He also makes use of stereotypes to strengthen the identity of his group and to vilify the opponents who are no longer part of the group. His use of terms like koinonia [fellowship] or filial language is also a powerful way to build the identity and social reality of his group.

\section{Inleiding Mag goed of sleg?}

Mag speel ' $n$ rol in elke faset van ons samelewing en is inherent deel van die manier waarop ons met mekaar omgaan deur onder andere taalgebruik. Die gebruik van taal is inderdaad een van die belangrikste maniere waarop mag in sosiale verhoudings uitgeoefen word, synde direk of indirek, veral omdat taal persepsies van realiteit en daarmee realiteit self bemiddel en selfs skep. Mag is nie inherent negatief of positief nie. Dit hang in 'n groot mate van die situasie af waarin mag funksioneer asook van die kriteria wat gebruik word om te bepaal of mag goed of sleg is. Positiewe magsuitoefening is nodig om die samelewing na behore te laat funksioneer. Mense soos die polisie, politici, skoolhoofde, gesinshoofde, besigheidsmense, ensovoorts moet almal bepaalde mag hê om na behore te kan funksioneer. Hoe die mag uitgeoefen word is bepalend vir die morele waardering daarvan. Dit kan maklik misbruik word deur die benadeling of beskadiging van mense of omgekeerd deur die onbillike bevoordeling van die self of die ander. Daar moet verder in gedagte gehou word dat daar nie 'n objektiewe 'standaard' bestaan waaraan mag gemeet kan word nie. Kulture verskil byvoorbeeld radikaal in dié verband; die wyse van sosiale gedrag hang dikwels van die sosiale dinamiek binne gemeenskappe af - party gemeenskappe se sosiale kodes het ' $n$ hoër toleransie vir geweld as ander. Dit bly tot 'n hoë mate sosiaal-kultureel bepaald. Om byvoorbeeld 'n leier van 'n groepsgeörienteerde gemeenskap in Afrika aan dieselfde magskriteria te onderwerp as die leier van ' $n$ individualistiese demokratiese gemeenskap in Europa sou net tot aansienlike misverstande kon lei.

Binne hierdie raamwerk gaan die wyse waarop die outeur van 1 Johannes taal as magsinstrument gebruik tekspragmaties ondersoek word. Motyer (1997:107) haal Rebell aan as hy die punt maak dat die hoofdoel van tekspragmatika is om die effek van 'n teks op die ontvangers te probeer bepaal. Daar is immers 'n verskil tussen wat 'n uitspraak 'beteken' en wat 'n uitspraak 'doen', 'n aspek waaraan beide taalhandelingsteorieë (kyk Staley 1988; Botha 1991:38) asook retorici (Vorster 1987:385) aandag gee. Motyer (1997:116) beskryf retoriese taalgebruik as 'techniques employed in order to exercise persuasive power' (kyk ook Lucianus [Nigrinus 35-36] vir die kragtige effek van retoriek).

Taal is 'n sosiale fenomeen waardeur sosiale realiteite geskep en beïnvloed kan word (Botha 1991:46-47) of ten minste die persepsies oor die realiteite bepaal kan word. In die konstruksie, verandering of bevestiging van realiteite dien taal as magsinstrument, beide positief en negatief. Odiam (1989:4) beklemtoon dat taal een van die belangrikste wyses is waarop mense beweeg word om op 'n sekere manier op te tree. 'Our social reality is largely constructed and renewed in conversations' (Ng 1996:194). Deur taal word mag uitgeoefen. Laat ons ondersoek instel na die maniere waarop die outeur van 1 Johannes taal as magsinstrument gebruik. Die tipe mag ter sprake asook die konteks moet in gedagte gehou word.

\section{Konflik in die Johannesbriewe - aan wie is die brief gerig?}

Die Johannese briewe leen sig ideaal tot so 'n ondersoek na magsuitoefening by wyse van taalgebruik, aangesien die dokumente in en as gevolg van 'n konfliksituasie ontstaan het. 
Konflik en mag is twee sye van dieselfde munt, aangesien konflik gewoonlik deur mag besleg word. In die geval van 1 Johannes was dit nie anders nie.

Om die dinamiek agter die magspel deur middel van taal in 1 Johannes na behore te kan beoordeel, moet daar allereers gekyk word na die aard van die konflik (kyk die deeglike bespreking in Brown 2003; Menken 2010; Van der Watt 2011). Reeds (ook?) in die Evangelie is daar spore van konflik en skeuring binne die groep van volgelinge van Jesus (Joh 6:6071 en miskien dui die figuur van Judas ook op onmin binne die groep van Jesus). In 1 en 2 Johannes lees ons ewe-eens van 'n skeuring in die groep (1 Joh 2:18-27; 4:1-6; 2 Joh 7-9 en miskien 3 Joh 9-10); die 'ander groep' is nie meer deel van die Johannese groep nie en kontak met hulle word ook nie aangemoedig nie (2 Joh 11). In 3 Johannes staan Diotrefes en die oudste nog midde in die stryd en die resultaat van die konflik is nog nie bekend nie. Die mening van sommige dat 3 Johannes daarom dus voor die ander twee briewe geskryf moes gewees het, oortuig egter nie heeltemal nie, omdat die probleme van 3 Johannes nie dieselfde is as die probleme in die ander twee briewe wat tot die skeuring gelei het nie.

Waaroor het die konflik(te) gegaan? Daar is twee tipes materiaal in die briewe wanneer dit by die beskrywing van die opponente kom, naamlik direkte en indirekte opmerkings (dit word 'indirek' genoem, aangesien dit nie honderd persent seker is dat die uitsprake spesifiek met die oog op die opponente geformuleer is nie. Dit kon ook retoriese uitsprake wees). Volgens die direkte gedeeltes (1 Joh 2:18-27; 4:1-6; 2 Joh 7-9) lyk dit of die opponente gebreek het met die gemeente vanweë die verskille oor die leer oor en van Jesus (Christologie) wat verband hou met die messiasskap, mensheid (1 Joh 2:22; 4:2; 2 Joh 7), en versoening van Jesus (1 Joh 2:2; 4:10; kyk Van der Watt 2011:1-7). Daarom word die opponente as Antichriste en valse profete gesien wat deur valse geeste gelei word (1 Joh 2:18-19, 22; 4:3-6). Hulle invloed moet ook nie onderskat word nie - hulle het selfs daarin geslaag om lede van die Johannese groep te mislei (1 Joh 2:26).

Indirekte opmerkings word hoofsaaklik in die hipotetiese en kontrasterende gedeeltes van 1 Johannes aangetref wat met die optrede van die opponente saamhang (1 Joh 1:6, 8, 10; 2:4, $6,9 ; 4: 20)$. Sulke indirekte opmerkings sluit moontlik in dat die opponente beweer dat hulle gemeenskap met God het en in die lig wandel, hoewel hulle in die duisternis leef (1 Joh 1:6; 2:9; Brown 1986). Volgens hulle ken hulle God, bly in Hom en het Hom lief, maar hulle kom nie God se opdragte na nie en haat hulle broers (1 Joh 2:4, 6, 9; 4:20). Tog beweer hulle dat hulle nie sonde het nie en bewys so dat hulle leuenaars is en maak God ook tot 'n leuenaar (1 Joh 1:6, 8, 10). Hulle het blykbaar ook die versoenende waarde van die kruis ontken (1 Joh 2:2; 4:10), waarskynlik omdat dit nie nodig geag is nie. As sodanig lyk dit nie of die opponente Jesus verwerp het nie, maar of hulle wel ' $n$ ander siening oor Jesus gehad het in vergelyking met die groep aan wie die brief gerig is. Beide groepe het ook profetiese aansprake gemaak en beweer dat die (G)gees hulle lei. Die konflik was dus binne-Christelik en het oor die outentieke interpretasie van die persoon van Jesus gegaan, natuurlik met al die konsekwensies wat daarmee saamhang. Die twee groepe het verskillende antwoorde op die vraag wie Jesus is gegee en so verskillend opgetree op grond van hulle verstaan.

Binne so ' $n$ raamwerk is 1 Johannes geskryf. 'n Belangrike vraag vir ons doeleindes is aan wie die brief gerig is, want dit medebepaal die tipe mag wat gebruik word. Die indruk in die literatuur word dikwels gelaat dat die brief die opponente in gedagte het en dat die uitsprake in 1 Johannes so geïnterpreteer moet word asof dit aan die opponente geskryf is. Dit beteken dat die voorwaardelike uitdrukkings (as ... dan) aan hulle adres gerig is met die doel om hulle te oortuig dat hulle verkeerd is. Hiervolgens sou die buitegroep aangespreek en aangeval word. Lieu (2008) het egter oortuigend aangetoon dat die brief nie aan die buitegroep geskryf is nie, maar aan die agtergeblewene groep. Dit verander die retoriese situasie natuurlik heeltemal. Wat gesê word is nie bedoel om die buitegroep aan te spreek nie, maar om die binnegroep te vermaan, te versterk en hulle identiteit op te bou in die lig van dit wat tussen hulle en die ander groep gebeur het. Magsuitoefening deur die taal en retoriek in 1 Johannes moet dus vanuit dié perspektief beoordeel word. Die retoriese hoofmodus is nie aanval nie, maar versterking.

Van die vernaamste elemente uit die 'arsenaal' wat deur die outeur gebruik word om sy mag uit te oefen gaan nou kortliks onder die soeklig kom. Die doel is nie ' $n$ detail bespreking van elke element nie (dit sou in elke geval 'n afsonderlike artikel vereis), maar om by wyse van ' $n$ aantal voorbeelde ' $n$ oorsigtelike beeld te vorm van hoe taal in die magspel gebruik is. Die skrywer benut die performatiewe eienskappe van taal, met ander woorde, daar gaan aangetoon word dat hy sy taal retories so benut dat hy die mense aktief in hulle aksies en denke oor hulleself wil beïnvloed. Elemente soos tradisiegebondenheid, stereotipes, sosiale- en identiteitsbeskrywings as beskrywings van aksies wat mag uitdruk gaan aandag ontvang. Dit gesê, moet een opmerking hier ernstig geneem word, naamlik, dit wat realistieserwyse ondersoek gaan word: alleen maar die poging van die outeur tot magsuitoefening deur die retoriese benutting van taal kan beskryf word. Van die effek daarvan op lesers kan niks gesê word nie, want ons het geen data oor hoe hulle op die lees van die teks gereageer het nie. Of die poging tot magsuitoefening suksesvol was of nie, kan dus nie vasgestel of bespreek word nie.

Voordat daar verder gegaan word, is dit teoreties belangrik om eers te vra of dit realisties is om van die performatiewe eienskap van taal, veral 'n antieke taal soos wat in 1 Johannes gebruik word, te praat. Is daar tekens uit die antieke tyd dat taal wel so gebruik is?

Olbricht (2003) beweer na deeglike analise van 'n groot hoeveelheid antieke tekste: 
The rhetorical features of ancient discourse are far more varied than the classical rhetoricians recognized. It is therefore important for those involved in rhetorical criticism of the Scriptures to give attention to what the Greco-Roman rhetoricians commented upon as well as what they did not. The rhetoricians conceived analogical features of discourse as essentially stylistic devices. (bl. 388-389)

Olbricht (2003:371-389) het verder aangetoon dat die antieke skrywers bewus was van verskillende vorms van performatiewe taal wat deur verskeie antieke retorici bespreek en gebruik is. Hy illustreer hoe antieke skrywers bewus was van die effekte van hulle taalgebruik (dit is, wat die taal doen eerder as wat die taal sê), onder andere om te plesier, of om die vertelling lewendig te maak. Hy toon ook aan hoe die antieke retorici meen dat met analogiese taalgebruik meer klem op die aangename en lewendige aspekte van taalgebruik gelê word as op die substansie van wat gesê word. Daar het egter 'n verandering gekom in die geskrifte van byvoorbeeld Filo of Klemens van Aleksandrië deurdat die substansie van wat gesê is ook meer op die voorgrond geskuif het. In Olbricht (2003:387) se woorde: 'Analogy for Philo therefore communicates an ontology, the aim for which is considerably different from that of the rhetoricians, for whom analogy is essentially mere vivacity of style.' Hierdie ander benadering word in die werk van Klemens van Aleksandrië en ook die Evangelie van Johannes bevestig (Van der Watt 2010:139-167). Olbricht (2003) konkludeer:

From an examination of the allegorical interpretation of Scripture in Philo and Clement of Alexandria we have a new vision of the manner in which analogies have rhetorical power ... The interpretation is typological. And typological interpretation must also be examined for how it functions rhetorically. (bl. 387-388)

Hy gaan verder en sê:

In the communication that took place in the church and synagogue, however, analogical approaches reflected a fundamental vision of reality. It is for this reason that increased attention needs to be given to how these features of religious discourses work as well as the manner in which they possess rhetorical power. (bl. 388-389)

Dit gaan vervolgens ook met 1 Johannes gedoen word.

Hieruit blyk dus dat die antieke outeurs deeglik bewus was van die performatiewe aard van die taal wat hulle gebruik het ten einde hulle kommunikatiewe oogmerke te bereik. Dit sou dus nie anachronisties wees om te vra of soortgelyke performatiewe taalgebruik in 1 Johannes voorkom nie.

\section{Tradisiegebondenheid as magsinstrument}

Die konsep etos is ' $n$ handige analitiese kategorie vir die beskrywing van die aard van die gedragspatrone in 1 Johannes. In die breë kan gesê word dat etos verwys na die gekanoniseerde konvensies van 'n spesifieke groep (of individu) - dit is wat jy van die groep se gedrag en hulle motivering daarvan sou verwag (kyk Theissen 1989;
Prostmeier 1990; Heiligenthal 1983; Schmeller 2001:133). Meeks (1993) stel dit so:

Our moral intuitions are those unreflective convictions about what is right or wrong, fair or unfair, noble or despicable, with which all the more complicated moral decisions must begin and which they must take into account. (bl. 8)

As 'n ouer vir 'n kind sê: 'Gedra jouself' word deur die twee woorde by die kind ' $n$ hele wêreld van assosiasies opgeroep waarvolgens hy sy gedrag moet oriënteer. Dit is die 'life-style of a group or society' (Keck 1974:490; kyk ook Furnish 1968). Wolter (2001) beskryf ewe-eens etos as:

...einen Kanon von institutionalisierten Handlungen, die innerhalb eines bestimmten sozialen Systems in Geltung stehen. Ihnen wird Verbindlichkeit zugeschrieben, weil allererst durch solche Handlungen eine bestimmte Gruppe als solche erkennbar und erfahrbar wird. (bl. 128)

Die term etos vestig dus die aandag dus op die feit dat daar vaste patrone van gedrag bestaan waarop die identiteit en aksies van die groep of individue gebou is (Sorokin 1948:381; Van der Merwe 2008:360; Mönnig 1980:32; Despres 1975:40).

Die etos van 'n groep vorm dus 'n soliede inhoudelike basis en oriënteringspunt waarop aansprake gemaak kan word, aangesien wat ' $n$ mens glo en weet in ' $n$ groot mate jou gedrag bepaal en dit is juis die basis en oogmerk van die magsuitoefening. As sodanig kan dit ook goed diens doen binne magsuitoefening en manipulasie.

'n Besondere kenmerk van 1 Johannes is die byna oorweldigende wyse waarop die skrywer appèl maak op bestaande kennis van die groep (hul etos) ten einde sy argument retories te versterk en so sy mag te (her)bevestig. Dit is belangrik om te sien dat hy nie uit die posisie van eksterne outoriteit, byvoorbeeld as profeet of oudste kom nie, maar as persoon wat binne die raamwerk van die etos en tradisie sy brief skryf. As verteenwoordiger hiervan het hy outoriteit.

In ' $\mathrm{n}$ relatief kort brief word daar ' $\mathrm{n}$ wye verskeidenheid woorde gebruik om na kennis of kennisverwerwing te

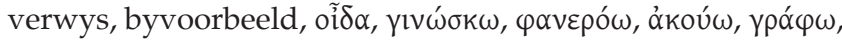
$\mu \alpha \rho \tau \cup \rho \varepsilon \varepsilon^{\prime} \omega, \grave{\alpha} \gamma \gamma \varepsilon \dot{ } \lambda \lambda \omega$ en sy derivate. 1 Johannes begin met ' $n$ aanduiding dat die brief op bestaande kennis, met ander woorde, tradisie gebaseer is, kennis wat deur die groep aanvaar en voortgedra word. Die kennis gaan terug na 'die begin' toe ("O $\tilde{\eta} v \alpha \dot{\alpha}]^{\prime} \alpha \rho x \tilde{\eta} \varsigma-1$ Joh 1:1), toe die Lewe, die Woord van die lewe, fisies ervaar is op grond van openbaring $(\dot{\eta} \zeta \omega \grave{\eta}$ $\dot{\varepsilon} \varphi \alpha v \varepsilon \rho \omega ́ \theta \eta$ - 1 Joh 1:2). Oor hierdie Lewe word daar getuig en

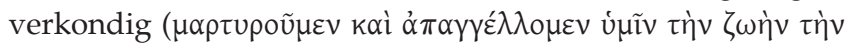

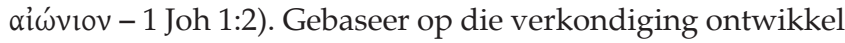
daar sterk onderlinge verhoudings binne die groep, met ander woorde, die samebinding berus op die inhoud van die getuienis. As iemand dus sou vra waarom hoort die groep saam of wat hulle identiteit is sal hulle in hulle antwoord terugval op hulle gedeelde kennis, oftewel hul etos.

Die kern van hulle kennis, met ander woorde, 'wat hulle geweet het', het rondom Jesus gesentreer, soos uit die proloog 
van die brief duidelik is, maar wat was die omvang van die gedeelde kennis van die groep? Wat het dit ingesluit? Die twee terme, oĩ $\delta$ ( 15 maal in 1 Johannes en 1 maal in 3 Johannes,

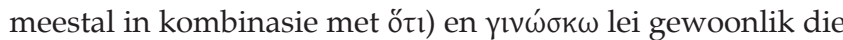
gedeeltes in waar aangedui word wat die groep geweet het. Oor hierdie twee woorde beweer Painter (2002:223): 'The two verbs seem to be used without difference in meaning.' In 1 Johannes 2:29 word die terme wel sonder skynbare verskil

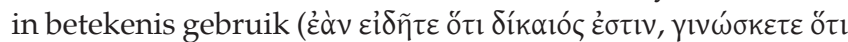
...), maar tog in 1 Johannes 5:20 word die twee werkwoorde saam gebruik, die een (oí $\delta \alpha \mu \varepsilon v)$ beklemtoon dat feite geken word en die ander ( $ү ı \omega \omega \sigma \kappa \omega \mu \varepsilon v)$ dat iemand geken word. Daar is dus tog op sommige plekke 'n meer gedifferensieerde gebruik van die terme. Klauck (1991:185) merk tereg op dat die 'julle weet' dele 'vorgegebene Glaubenstraditionen ins Spiel' bring.

Die kennis wat die groep gedeel en wat hulle etos bepaal het kan so opgesom word op grond van die kontekste waarin bogenoemde twee terme gebruik word.

- Jesus het aan hulle begrip gegee sodat hulle Hom ken en in Hom is wat waar is. (1 Joh 5:20). Hulle ken God en Christus (1 Joh 2:13-14; 1 Joh 4:7; 1 Joh 5:20), maar die wêreld nie (1 Joh 3:1, 6). Die groep was dus intiem bewus van hulle verhouding met die Vader en die Seun.

- Hulle het lewe (het van dood na lewe oorgegaan) omdat hulle uit God gebore is (1 Joh 3:14-15; 5:13, 18, 19). Hulle was bewus van hulle nuwe identiteit as mense wat nuut gebore is en so die ewige lewe ontvang het.

- Hulle ken die waarheid (1 Joh 2:20-21; 1 Joh 5:20; 2 Joh 1). Hulle is bewus van die goddelike dimensies wat hulle lewens nou bepaal en rig.

- Jesus het die sonde weggevat en oorwin (1 Joh 3:5). Die Bose het geen greep op die kind van God nie (1 Joh 5:18). Hulle verhouding met God word nie meer deur sonde bederf nie. Daarom kan hulle 'n oorwinnende lewe lei.

- Hulle ken die liefde wat God vir ons het (1 Joh 4:16). Hulle lewens word nou bepaal deur nuwe morele riglyne, naamlik die liefde van God.

- Jesus is regverdig en hulle moet regverdig wees (1 Joh 2:29). Hulle lewens moet nou sonder sonde geleef word in lyn met die verwagtinge van God van wat reg is.

- God luister na hulle en daarom kan hulle vra wat hulle wil volgens Sy wil (1 Joh 5:15). Hulle het nou vrymoedigheid om met God te praat, op Sy betrokkenheid in hulle lewens staat te maak.

- Jesus kom weer en dan sal die kinders van God soos Hy wees (1 Joh 3:2). Hulle kan vanuit hul eskatologiese verwagtings leef.

Uit hierdie samevatting blyk dat die gemeente se kennis die hele spektrum van lewe gedek het, van die punt af waar hulle hul nuwe identiteit kry tot by hul eskatologiese verwagtings, wat beteken dat die outeur meen dat die groep omvattend vertroud is hulle nuwe geboorte wat gelei het tot hul identiteit as kinders van God, met wat eties van hulle verwag word met die fokus op om te doen wat Jesus gedoen het, met die verwagtinge oor die toekoms en versekering dat God na hulle gebede luister. Al hierdie aspekte word in die Evangelie ook bespreek; die verband met die Evangelie kan dus nie ontken word nie. Die ontvangers van die brief moes met die basiese inligting van die Evangelie vertroud gewees en dit aanvaar het.

Verwysings na wat hulle gehoor (ákoúw) het, is 'n ander wyse waarop die outeur hulle bestaande kennis beklemtoon (kyk 1 Joh 1:1-4). Soos verwag kan word, oorvleuel wat hulle gehoor het en wat hulle weet in 'n groot mate, hoewel daar tog verskille is:

- Hulle het die Woord van Lewe van die begin af gehoor en het van Jesus ook gehoor (1 Joh 1:1, 3; kyk ook 1 Joh 2:24). Hulle is vertroud met die tradisie.

- Hulle het die boodskap gehoor dat God lig is (1 Joh 1:5). Hulle is verbonde aan die God wat lig is, met ander woorde die ware God.

- Hulle het 'n ou gebod van die begin af gehoor (1 Joh 2:7). Hulle godsdiens is gebaseer op die oorspronklike gebod van God. Dit is nie iets nuuts nie. Dit verleen outensiteit aan hulle posisie.

- Hulle moet mekaar liefhê soos hulle van die begin af gehoor het (1 Joh 3:11; 2 Joh 6). Hulle staan binne die tradisie van liefde.

- Hulle het van die Antichris gehoor wat op pad is (1 Joh 2:18; 1 Joh 4:3). Hulle staan binne die tradisie van die apokaliptiese verwagting van die Bose wat aan die einde sal kom.

Die outeur noem verder dikwels dat hy 'hierdie dinge skryf' ( $\tau \alpha \tilde{v} \tau \alpha$ $\gamma \rho \alpha ́ \varphi \omega)$ en dan verwys $\tau \alpha \tilde{v} \tau \alpha$ na die inhoud van hul kennis en wat in die brief beskryf word (1 Joh 1:4; 1 Joh 2:1, 26; 1 Joh 5:13). Dit gaan dus oor dinge wat binne hulle kennisraamwerk en etos van die groep inpas, naamlik dat hulle die Vader en Seun ken, dat hulle sondes vergewe is en dat hulle nie meer moet sondig nie, of dat hulle die waarheid ken. Die retoriese effek van sy skrywe is dus om by die kennis van die groep aan te sluit en retories van daaruit te argumenteer. Dit plaas die outeur in 'n posisie van mag, wat eintlik gebaseer is op die aanvaarde outoriteit van die etos van die groep. Die verbondenheid met die etos verleen gesag aan wat hy sê.

'n Verwante wyse om retories mag deur taal in 1 Johannes uit te oefen, is om iets wat gebeur religieus positief te dui.

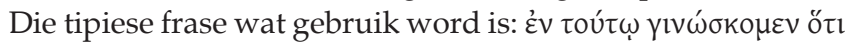
[hierin weet ons dat ...], met ander woorde, as jy die een ding doen kan jy die ander aanneem (weet). Daar word nie oor geargumenteer nie, maar die feit word eenvoudig gestel en so word die groep op 'n outoritatiewe manier met ' $n$ gegewe gekonfronteer. As daar nie hierby ingeval word nie, word die teendeel eenvoudig van diegene waar. Hier volg enkele voorbeelde:

TABEL 1: Doen en leer.

\begin{tabular}{|c|c|c|}
\hline Vers & Wat jy doen & Wat jy leer \\
\hline $2: 3$ & 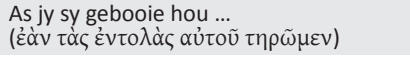 & 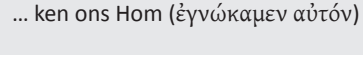 \\
\hline $2: 5$ & 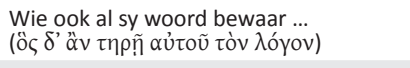 & ... is ons in Hom ( $\left.\varepsilon^{\prime} v \alpha u \dot{\tau} \tau \tilde{\varphi} \tilde{\varepsilon} \sigma \mu \varepsilon v\right)$ \\
\hline $4: 6$ & 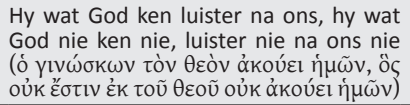 & 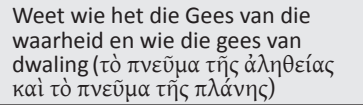 \\
\hline
\end{tabular}


Dit beteken dus dat die mense wat die gebooie hou of Jesus se woord bewaar (soos dit deur die outeur as verteenwoordiger van die tradisie geformuleer word) ook diegene is wat 'in Hom is en Hom ken.' Die omgekeerde is ook waar. So word 'n spesifieke waarheidsraamwerk bewustelik geskep, sonder argumentasie, maar vanuit die mag en gesag wat die outeur het as verteenwoordiger van die etos.

In kort, deur na spesifieke kennisinhoude oor God, verlossing, identiteit, etiek, die toekoms ensovoorts te verwys word ' $n$ outoritatiewe raamwerk geskep waardeur mense positief of negatief beoordeel word. So funksioneer dit as magsinstrument om nie alleen sekere posisies te kondoneer nie, maar ander persone of groepe as sonder kennis en sonder die Gees te diskwalifiseer. Malina en Neyrey (1991; kyk ook Malina \& Rohrbaugh 1998:33) noem laasgenoemde 'negative labeling':

Negative labels, in fact, are accusations of deviance. Behavior is deviant when it violates the sense of order or the set of classification which people perceive to structure their world. (bl. 100)

Deur die opponente te 'label' as sonder die bepaalde kennis en dus sonder die tradisie wat van die begin af was (1 Joh 1:1-4), word hulle as afwykend en dus negatief getipeer. So word ' $n$ negatiewe realiteit rondom hulle geskep en word die gevoel van 'korrektheid' aan die kant van die Johannese groep versterk.

Die kennisinhoude van die groep self en hul hantering daarvan word deur die outeur versterk deur na die outentieke teenwoordigheid van die Gees te verwys. Dit is die Gees wat binne die tradisie sorg dat mense op die regte pad bly. Die werking van die Gees word ook getoets aan die belydenis rondom Jesus, met ander woorde, die korrekte Jesustradisie soos die outeur en waarskynlik ook sy groep dit sien (1 Joh 4:1-2). Uiteindelik dien die etos as toetssteen vir die werk van die Gees. Wie met ander woorde nie die tradisies soos die outeur onderskryf nie, word as valse profete beskryf. Mense wat die salwing het, sal weet wat die waarheid is (1 Joh 2:20-27) en sal die nodige onderskeidinge kan tref - die ander nie. So word die outoriteit van die Gees by die siening van die tradisie betrek.

\section{Stereotipes - bevestiging van die eie identiteit en disassosiasie van opponerende groepe}

Binne die raam van onder andere sosiale identiteitsteorieë ('n benadering wat begin is deur Tajfel \& Turner in 1979; kyk ook hul 1986 artikel), word stereotipes of 'kategorisering' as een van die basiese maniere gesien om identiteit te vestig en af te perk. Dit is ' $n$ wyse van sosiale stratifikasie. Aristoteles was reeds deeglik bewus hiervan en het gesorg vir ' $n$ hele klassifikasie van voorbeelde wat retories vir klassifikasie benut kan word. Olbricht (2003) bespreek Aristoteles se benadering en sê dan:

Two major terms employed by Aristotle in regard to comparison

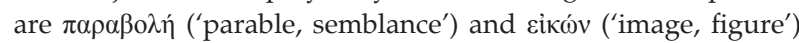

... The examples are further divided into two kinds: those that have happened, which we may designate historical, and those invented, that is, comparisons $(\pi \alpha \rho \alpha \beta o \lambda \eta ́)$ or fables $(\lambda o ́ \gamma o \imath) . . . \mathrm{He}$ (Aristotle) argued that even though fables are easier to come upon than historical comparisons, '...those derived from facts are more useful for deliberative oratory, because as a rule the future resembles the past. (bl. 373)

Figure, (veral figure wat as die historiese figure binne die geheue van 'n groep figureer), wat tipologies die kwaliteite van 'n spesifieke groep verteenwoordig en dus nagevolg moet word, staan sentraal binne die sosiale identiteitsbewussyn van die groep. Deur sulke tipologiese stereotipes retories te gebruik word mense effektief gekategoriseer, hetsy positief of negatief deur die proses van assosiasie. Dit word dus 'n effektiewe instrument van magsuitoefening en magsvestiging binne gemeenskappe. Die inkleding van hierdie tipologiese figure en die assosiasies (positief of negatief) wat met hulle gemaak word bepaal die kwalitatiewe aard van die gemeenskappe ter sprake. Die outeur van 1 Johannes maak ruimskoots en effektief hiervan gebruik. Enkele voorbeelde is negatief - Kaïn, die Antichris, kinders van die duiwel en positief - Jesus of Abel, die broer van Kaïn. Culpepper (1983) het die tema van karakterisering en die benutting daarvan opnuut aangeroer wat gelei het tot 'n stortvloed van artikels oor die karakters in die Johannese literatuur, veral in die Evangelie. (Die lys publikasies oor die onderwerp is lank - kyk na die resente boek van Bennema [2009] vir 'n goeie oorsig oor die navorsing). Dit het die retoriese belang van karakters onderstreep, ook vir die persepsie-ervaring binne die Johannese groep.

In 1 Johannes 3:11-17 word Kaïn in herinnering geroep as die rebelse broer wat die konvensionele verwagtings binne die familie verontagsaam het en sy broer doodgemaak het. Vanuit die Ou-Testamentiese verhaal in Genesis 4 is Kain assosiatief die stereotipe van iemand wat teen God sondig en sy eie groep skade berokken. Deur die groep opponente in 1 Johannes retories en assosiatief implisiet met Kaïn te verbind klassifiseer hulle onmiddellik as sondaars wat teen God se wil optree deur sy familie (die kinders van God) skade te berokken (kyk Thatcher 2010 vir 'n breed uitgewerkte beskrywing van Kain as stereotipe). Daarmee is die opponente deur middel van een verhaal magsvol gediskrediteer. Dit toon die performatiewe mag van stereotipisering by wyse van tipologie.

Die opponente word ook met behulp van die term 'Antichriste' negatief getipeer en gevilifiseer (vir ' $n$ uiteensetting van vilifikasie kyk Du Toit 1994:403-412; Lausberg 1960:55, 61; 131-138; 205-206; 542). Op die manier disassosieer die outeur homself en sy groep van die opponente (Du Toit 1994:404; Johnson 1989:419-441). Dit is nie heeltemal seker waar die begrip 'Antichris' vandaan kom nie, maar hou waarskynlik verband met die bose apokaliptiese figuur wat aan die einde van die tyd verwag is, soos 1 Johannes dit ook stel (1 Joh 2:18). Die een Antichris wat verwag is, word in 1 Johannes baie Antichriste, verwysende na die opponente (1 Joh 2:19). Retories word die Antichris as die bose opponent van Christus tipologies met die opponente verbind, wat dan 
aan die stereotipering van die bose Antichris deel. Hulle is nou ook Antichriste, met ander woorde, soos die Antichris. Deur die mag van taal en die gebruik van tipologie perk die skrywer sy groep van die ander groep af en karakteriseer hulle negatief. Om dit anders te stel: die woorde van die outeur maak die opponente Antichrist in die oë van die Johannese groep - dit deur die mag van taal. So word die ontvangers van die brief ' $n$ positiewe identiteit toegesê en die opponente negatief gekarakteriseer. Daar is nog ' $n$ hele aantal voorbeelde, soos Jesus wat die tipe van die gemeente is, maar daar moet vanweë spasie hiermee volstaan word.

\section{Sosiale- en identiteitsbeskrywings}

1 Johannes se wortels lê binne 'n spesifieke konfliksituasie wat sosiaal op skeuring uitgeloop het, met ander woorde, wat een was het twee geword. Natuurlik sou beide nuwe groepe elemente bevat van die oorspronklike Christelike groep wat geskeur het: byvoorbeeld, beide sou aanspraak maak op die leiding van die Gees (1 Joh 4:1 en verder), beide het Jesus skynbaar bly bely, hoewel verskillend. So 'n situasie van skeuring vra outomaties vir verheldering van grense, juis omdat die twee groepe uit dieselfde oorspronklike groep stam en dus aan die kwaliteite van die oorspronklike groep deel het. As beide aanspraak maak op die Gees of op Jesus moet daar duidelike grense kom, want 'n skeuring veronderstel twee onderskeibare posisies. Dit is juis by die trek van die sosiale grense waar outoriteit en mag op die spel kom (vir die situasie in die Johannesevangelie kyk Rebell 1987). In 1 Johannes word daar ' $n$ verskeidenheid van identiteitsbeskrywings gevind wat die Johannese groep identiteitsgewyse afperk van die ander groep. Stereotipes wat hierbo beskryf is, is een, maar nie die enigste manier nie. Daar moet ook in gedagte gehou word dat die beskrywings vir die gemeente se opbou bedoel is - die brief is aan hulle geadresseer en nie aan die opponente nie. Dit weerspieël dus meer van 'n binnegesprek wat moet versterk en motiveer as 'n openlike geveg na buite met die opponente.

Die skrywer van 1 Johannes begin sy brief deur sy groep intiem met mekaar en met die Vader en Seun te verbind deur die gebruikmaking van die term koinōnia (1 Joh 1:4-7). In 1 Johannes 1:6-7 lees ons:

As ons sê dat ons koinōnia met hom het, en ons wandel in die duisternis, lieg ons en doen ons die waarheid nie; maar as ons in die lig wandel soos $\mathrm{Hy}$ in die lig$^{1}$ is, het ons koinōnia met

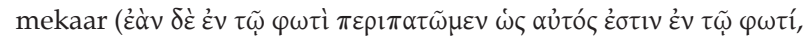

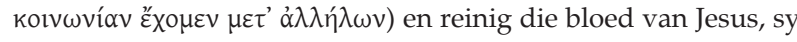
Seun, ons van elke sonde.

Hoewel die term koinōnia nie ' $\mathrm{n}$ tipies Johannese term is nie (Painter 2002:151-152; Smalley 2002:12-13,23; Klauck 1991:70; Menken 2010:24) word dit hier gebruik vir identiteitsvorming en -bevestiging. Koinōnia is een van die kragtigste Griekse terme om intieme persoonlike verhoudings mee te tipeer.

1.Barrett (1978:335) bespreek die moontlike agtergronde vir die metafoor van lig wat algemeen in die Johannese literatuur gebruik word, maar Pancaro (1975:485) is pessimisties of die werklike oorsprong van die beeld ooit gevind sal kan word. Deel van die kompleksiteit lê in die feit dat dit as universele of argitipiese beeld gesien word (Menken 2010:27). Culpepper (1983:191) noem dat die simbool van lig diep word (Menken 2010:27). Culpepper (1983:191) noem dat die simbool van lig diep
wortels in die Hellenisme en Judaïsme het (kyk ook Ashton 1991:208-214; Koester wortels in die Hellenisme en Judaïsme het
1995:123-154; Petersen 1993:72-109).
Die outeur gebruik die term nie alleen om die verhouding tussen die Johannese groep onderling te beskryf nie, maar ook tussen die groep en die Vader en Seun (1 Joh 1:3-4). So word die groep aan wie die brief geskryf word binne die 'goddelike ruimte' opgeneem. Die 'goddelike ruimte' word verder in die konteks metafories beskryf as 'lig'. God is lig (1 Joh 1:5) en as daar in die lig gewandel word, is dit 'n bevestiging van die intieme verhouding (koinōnia) tussen die persoon en God (kyk Brown 1986:195-198; Olsson 1999:149; Klauck 1991:70-71, 81). Die konsep koinōnia fokus semanties op interpersoonlike kwaliteite soos om alles met mekaar te deel (om een 'siel' te wees), om tot die uiterste vir mekaar om te gee en mekaar te versorg, om lojaal te bly al kos dit wat (kyk Aristoteles Nic Eth. 8.ix.1-2; Plutarchus Flatterer 24, Mor. 65AB; Martial Epigr. 2.43.1-16; Cornelius Nepos Vir. Illus. 15.3.4; Diogenes Laertius Vit. 7.1.124; Plato Lysis 207c; kyk ook Stählin 1964-1976, 9:152). Die grense tussen die persoonsbelange van persone wat koinōnia met mekaar het word proieus, met ander woorde, belange, gedagtes, die wil, ensovoorts vervloei en smelt saam (Klauck 1991:70-71). Brown (1986:170) beskryf dit as 'the dynamic esprit de corps that brings people together' wat die resultate van so ' $n$ gees van saamwees insluit.

Arndt (2000:s.p.; kyk ook van der Merwe 2006:542; Louw \& Nida 1996) beskryf dit soos volg:
... close association involving mutual interests and sharing, association, communion, fellowship, close relationship (hence a favorite expression for the marital relationship as the most intimate between human beings ... the common type or bond of life that unites people ... (harmonious) unity ... attitude of good will that manifests an interest in a close relationship, generosity, fellow-feeling, altruism ... participation, sharing ... the common possession or enjoyment of something $\ldots$ or the common possession or enjoyment of virtues.

Deur die pregnante begrip koinōnia aan die Johannese groep te koppel slaag die outeur daarin om die grense van die groep konkreet te trek en sodoende bepaalde sosiale verwagtings te skep. Dit gaan oor mense wat in 'n verhouding van gemeenskaplike vertroue, mededeelsaamheid, versorging ensovoorts, leef. Dit is konkreet identifiseerbaar en daarom kan die opponente getipeer word as 'nie meer van ons nie' (1 Joh 2:19) of dat hulle soos Kaïn hulle eie familie 'vermoor' het (1 Joh 3:12), 'n metaforiese beskrywing van die feit dat hulle nie meer die groep liefhet nie (kyk die konteks van 1 Joh 3:11-18). Hulle vorm konkreet nie meer deel van die intieme groep wat sigbaar is deur die koinōnia van 'n intieme onderlinge verhouding en die gepaardgaande sosiale interaksie nie. Olsson (1999:149) wys dan ook daarop dat woorde wat die intieme onderlinge verhouding tussen die Johannese groep beskryf, in kontras met die opponente, dwarsdeur die brief voorkom - hy verwys na woorde soos liefde, geboorte, kennis, ensovoorts.

Deur sy brief met so 'n kragtige intieme verhoudings beskrywing te begin, vestig die outeur grense wat die res van sy betoog gaan tipeer. Daar is mense wat in koinōnia leef en ander wat nie daaraan deel het nie. Die wat nie in die intieme verhouding met mekaar leef nie, is nie van die lig 
nie, maar van die duisternis, en is verwyderd van God as sy opponente. Die realiteit word performatief deur taal geskep wat hier as magsinstrument duidelik sigbaar is. Op die wyse word magsvol gestel dat die teenwoordigheid van God in die Johannese groep aanwesig is. Dit dien as versterking vir hulle.

'n Tweede voorbeeld van die performatiewe manier waarop die outeur opponente deur die mag van taalgebruik uitskakel, is die gebruik van die begrip sonde ( $\dot{\alpha} \mu \alpha \rho \tau i ́ \alpha)$. In Jesus is daar geen sonde nie (1 Joh 3:5) en dieselfde behoort waar te wees van die kind van God (1 Joh 3:6, 9; Brown 1986:403; Painter 2002:227), soos die outeur dit self in 1 Johannes 3:9-10 stel:

Elkeen wat uit God gebore is, doen geen sonde nie, omdat sy saad in hom bly; en hy kan nie sondig nie, omdat hy uit God gebore is. Hierin is die kinders van God en die kinders van die duiwel openbaar: elkeen wat die geregtigheid nie doen nie, is nie uit God nie, asook hy wat sy broeder nie liefhet nie.

Soos Jesus wat die werke van die duiwel vernietig het (1 Joh 3:8) moet gelowiges ook die oorwinnende lewe oor die sonde leef (1 Joh 2:13; 5:4-5; Lingad 2001:215). Die optrede van persone illustreer konkreet aan watter groep hulle behoort en in die volgende perikoop (1 Joh 3:11-18) word dit geillustreer aan die hand van die voorbeeld van Kaïn en sy broer.

Natuurlik gebeur dit dat persone uit die Johannese groep wel foute maak, die grense van wat God (en die groep) wil oorskry en dus ook sonde doen (1 Joh 1:7-2:2). Die wyse waarop die probleem opgelos word fokus op die herstel van die verhouding deur belydenis, vergifnis reiniging en versoening (1 Joh 1:8-9; 2:1-2). Op die wyse word die ideaal van koinōnia behou (1 Joh 1:6-7).

Bogenoemde voorbeelde (en daar is meer) illustreer hoe die performatiewe gebruik van taal binne die magstryd met die opponente die eie groepsidentiteit versterk, verwagtinge skep ten opsigte van hulle optrede en die opponente negatief dui. Hier is dus sprake van positiewe magsgebruik ten einde die posisie binne die eie groep te versterk. 'n Mens sou hier kon vra wat die reaksie van die opponente hierop kon gewees het. Die brief is natuurlik nie aan hulle geskryf nie en is dus ook nie retories so geformuleer dat hulle dit moes lees nie. Die logiese antwoord in die geval blyk te wees dat die opponente uit ' $\mathrm{n}$ ander hoek en met ander voorveronderstellings na die hele konflik sou gekyk het en waarskynlik dieselfde gevoelens teenoor die Johannese groep gekoester het as wat in die brief teenoor hulle weerspieël word. Wat ons dus in die brief het is ' $n$ magsaksie vanuit ' $n$ bepaalde ideologiese hoek, wat met die ortodokse tradisie verbind is, ten einde die identiteit van die Johannese groep te (be)vestig en te versterk en die opponente te diskrediteer en hulle eintlik in relasie tot sy groep heeltemal te ontmagtig. Natuurlik sou die Johannesgroep die retoriek wat in 1 Johannes voorkom in die konflik teenoor die opponente kon gebruik het, maar dit lyk nie die doel met die brief te gewees het nie.

Die breë religieus-kosmologiese struktuur wat die outeur kies om sy boodskap binne die konflik aan te bied, plaas hom ook in 'n magsposisie. Hy werk, soos die Johannesevangelie, met ' $n$ dualistiese struktuur waar daar geen grysgebiede is nie, alleen maar lig of duisternis, waarheid of leuen, lewe of dood (Lincoln 2000:20). Motyer (1997:186-190) het aangetoon dat dualistiese strukture, veral etiese strukture, bekend was in die Tweede Tempel Judaïsme (bv. in die Kumranliteratuur [1QS 3:19-21, 4:15-16; 4QFlor 1:8], Testament van die Twaalf Patriarge [T. Reu 2:1; 3:2; 4:7; Lev 3:3; T. Zeb 9:8; T. Ash. 1:8f.; 3:2; 6:5; Jud. 19:4; T. Dan 1:7f.,5:1] en in die Palestynse Tragums oor Gen 3 [Tg. Ps.-J. on Gen 3:6]). Dit vergemaklik klassifikasie aansienlik, aangesien onderskeiding tussen wie in die lig of wie in die duisternis is, in meer absolute taal maar ook meer spesifiek gemaak kan word. Voorbeelde hiervan op etiese vlak is byvoorbeeld die voorbeeld van God wat lig is; iemand wat sê dat hy in 'n verhouding met God staan en doen wat met die duisternis of sonde geassosieer kan word, is kategories nie 'in God' nie. So 'n persoon staan dus nie in verhouding met God nie. Die omgekeerde is net so waar (1 Joh 1:6-8). Of, wie die groep skade doen soos Kaï wat sy familie doodgemaak het, kan ook nie sê dat hulle deel van die familie is nie, inteendeel, hulle is moordenaars (1 Joh 3:11-18). Daar is nie ' $n$ middelweg nie, met ander woorde, die persoon is óf aan die kant van die outeur en derhalwe God óf hy of sy is in die duisternis as kind van die duiwel.

\section{Enkele samevattende opmerkings}

Uit die voorafgaande het duidelik geword hoe mag deur middel van taalgebruik in 1 Johannes uitgeoefen is (kyk ook Van der Watt 2010:139-167). Die outeur het deur sy woordgebruik en woordkeuses, die beelde wat gebruik is om sosiale konstrukte te skep, sy assosiasie met die tradisie en so meer, die identiteit en selfverstaan van sy lesers positief probeer beïnvloed. Sy brief was nie aan die opponente gerig nie, maar aan sy eie groep, wat beteken het dat hy binne die groep performatief sake wou aanspreek en beïnvloed. Ook die negatiewe taal waardeur die opponente gekarakteriseer is, moes deur kontrastering bydra tot die positiewe vorming van die ontvangers van die brief.

Dit is natuurlik nie bepaalbaar hoe suksesvol die magsuitoefening was nie - ons het alleen die tekens van die poging tot magsuitoefening deur taal (met ander woorde, alleen maar die een kant), maar nie tekens van die ontvangs van die brief of die resultate daarvan is beskikbaar nie. Wat wel waarskynlik enkele jare hierna gebeur het is dat die Johannese groep 'verdwyn' het, hetsy deur in 'n meer gnostiese rigting te beweeg of deur in die Christelike hoofstroom opgeneem te word.

\section{Erkenning Mededingende belange}

Die outeur verklaar dat hy geen finansiële of persoonlike verbintenis het met enige party wat hom nadelig kon beïnvloed in die skryf van hierdie artikel.

\section{Literatuurverwysings}

Arndt, W., Danker, F.W. \& Bauer, W. [BDAG], 2000, A Greek-English lexicon of the New Testament and other early Christian literature, University of Chicago Press, Chicago.

Ashton, J., 1991, Understanding the Fourth Gospel, OUP, Oxford. 
Barrett, C.K., 1978, The Gospel according to St John, SPCK, London.

Bennema, C., 2009, Encountering Jesus: Character studies in the Gospel of John Paternoster, Milton Keynes.

Botha, J.E., 1991, Jesus and the Samaritan woman: A speech act reading of John 4:1-42, Brill, Leiden.

Brown, R.E., 1986, The Epistles of John, Doubleday, New York.

Brown, R.E., 2003, An introduction to the Gospel of John, ed. F.J. Moloney Doubleday, New York.

Culpepper, R.A., 1983, Anatomy of the Fourth Gospel: A study in literary design, Fortress, Philadelphia.

Despres, L.A., 1975, 'Toward a theory of ethnic phenomena', in L.A. Despres (ed.) Ethnicity and resource competition in plural societies, pp. 187-195, Mouton, Den Haag.

De Vaux, R., 1974, Ancient Israel: Its life and institutions, Longman and Todd, London.

Du Toit, A.B., 1994, 'Vilification as pragmatic device in Early Christian epistolography', Biblica 75(3), 403-412.

Furnish, V.P., 1968, Theology and ethics in Paul, Abington Press, New York.

Gilbertson, M.T., 1959, The way it was in Bible times, Augsburg, Minnesota.

Heiligenthal, R., 1983, Werke als Zeichen, Mohr Siebeck, Tübingen.

Johnson, L.T., 1989, 'The New Testament's anti-Jewish slander and the conventions of ancient Polemic', Journal of Biblical Literature 108, 419-441. http://dx.doi. org/10.2307/3267112

Keck, L.E., 1974, 'On the Ethos of Early Christians', Journal of the American Academy of Religion 42, 435-452. http://dx.doi.org/10.1093/jaarel/XLII.3.435

Klauck, H-J., 1991, Der erste Johannesbrief, Benziger Verlag, Zürich.

Koester, C.R., 1995, Symbolism in the Fourth Gospel: Meaning, mystery, community, Fortress, Minneapolis.

Lausberg, H., 1960, Handbuch der literarischen Rhetorik, Max Hüber Verlag, München. Lieu, J.M., 2008, I, II, \& III John: A commentary, Westminster John Knox, Louisville.

Lincoln, A.T., 2000, Truth on trial: The lawsuit motif in the Fourth Gospel, Hendrickson, Peabody.

Lingad, C.G., 2001, The problems of Jewish Christians in the Johannine community, Gregoriana, Rome.

Louw, J.P. \& Nida, E.A., 1996, Greek-English lexicon of the New Testament: Based on semantic domains, United Bible societies, New York.

Malina, B.J. \& Neyrey, J.H., 1991, 'Conflict in Luke-Acts: Labeling and Deviance Theory', in J.H. Neyrey (ed.), The Social World of Luke-Acts: Models for Interpretation, pp. 97-122, Hendrikson, Peabody.

Malina, B.J. \& Rohrbauch, R.L., 1998, Social-science commentary on the Gospel of John, Fortress, Minneapolis.

Meeks, W.A., 1993, The origins of Christian morality: The first two centuries, Yale University Press, New Haven.

Menken, M., 2010, 1, 2 en 3 Johannes: Een praktische bijbelverklaring, Kok, Kampen.

Mönnig, H.O., 1980, Groepsidentiteit en groepswrywing: enkele waarneminge oor ras, rassisme, volk en etnisiteit, nasie en nasionalisme, Perskor, Johannesburg.

Motyer, S., 1997, Your father the devil? A new approach to John and 'the Jews', Paternoster, Carlisle.

Ng, S.H., 1996, 'Power: An essay in honor of Henri Tajfel', in W.P. Robinson (ed.) Social groups and identities: Developing the legacy of Henri Tajfel, pp. 191-214, Heinemann, Oxford.

Odiam, A.R., 1989, The rhetoric of the Fourth Gospel: A key to preaching, UMI, Ann Arbor.
Olbricht, T.H., 2003, 'Analogy and allegory in classical rhetoric', in J.T. Fitzgerald, T.H. Olbricht \& L.M. White (eds.), Early Christianity and classical culture: Comparative studies in honor of Abraham J. Malherbe, pp. 371-389, Leiden/Boston, Brill.

Olsson, B., 1999, 'DEUS SEMPER MAIOR? On God in the Johannine writings', in J. Nissen \& S. Pedersen (eds.), New Readings in John: Literary and theological perspectives, pp. 143-171, T\&T Clarke, London.

Painter, J., 2002, 1, 2, and 3 John, Liturgical Press, Collegeville.

Pancaro, S., 1975, The Law in the Fourth Gospel: The Torah and the Gospel, Moses and Jesus, Judaism and Christianity according to John, Brill, Leiden.

Petersen, N.R., 1993, The Gospel of John and the sociology of light, Trinity Press, Valley Forge.

Prostmeier, R., 1990, Handlungsmodelle im ersten Petrusbrief, Echter Verlag, Würzburg.

Rebell, W., 1987, Gemeinde as Gegenwelt: zur soziologischen und didaktischen Funktion des Johannesevangeliums, Lang, Frankfurt.

Schmeller, T., 2001, ,Neutestamentliches Gruppenethos', in J. Beutler (ed.), Der neue Mensch in Christus, pp. 120-134, Herder, Freiburg.

Smalley, S.S., 2002, 1,2,3 John, Word, Dallas.

Sorokin, P.A., 1948, Society, culture and personality - their structure and dynamics: A general system of sociology, Harper, New York.

Stählin, G., 1964-1976, 'Phília et alii', in G. Friedrich (ed.), Theological dictionary of the New Testament, vol. 9, pp. 147-171, online edition, Eerdmans, Grand Rapids.

Staley, J.L., 1988, The print's first kiss: A rhetorical investigation of the implied reader in the Fourth Gospel, Scholars Press, Atlanta.

Tajel, H. \& Turner, J.C., 1986, 'The social identity theory of inter-group behavior', in S. Worchel \& L.W. Austin (eds.), Psychology of Intergroup Relations, pp. 33-47, Nelson-Hall, Chicago.

Thatcher, T., 2010, 'Cain the Jew the Antichrist: Collective memory and the Johannine ethic of loving and hating', paper read on Ethics at John Congress, Radbound University, Nijmegen, 05 May.

Theissen, G., 1989, Soziologie der Jesusbewegung, Kaiser, München.

Van der Merwe, D.G., 2006, 'A matter of having fellowship: Ethics in the Johannine epistles', in J.G. van der Watt (ed.), Identity, ethics, and ethos in the New Testament, pp. 535-563, De Gruyter, Berlin.

Van der Merwe, J.P., 2008, 'Waardes as kultuuraspek van die Afrikaner' Journal of Humanities 48(3), 357-373.

Van der Watt, J.G., 1995, “"Metaphorik” in Joh 15, 1-8', Biblische Zeitschrift 38(1), 67-80.

Van der Watt, J.G., 1999, 'Ethics in 1 John: a literary and socio-scientific perspective', Catholic Biblical Quarterly 7, 1-21.

Van der Watt, J.G., 2000, Family of the King: Dynamics of metaphor in the Gospel according to John, Brill, Leiden.

Van der Watt, J.G., 2010, 'Ethics through the power of language: Some exploration in the Gospel according to John', in R. Zimmermann \& J.G. van der Watt (eds.), Moral language in the New Testament, pp. 139-167, Mohr Siebeck, Tübingen.

Van der Watt, J., 2011, '1, 2 en 3 Johannes: 'n Oorsig van die huidige stand van navorsing oor die inleidingsvraagstukke', HTS Teologiese Studies/Theological Studies 67(1), Art. \#867, 7 pages. http://dx.doi.org/10.4102/hts.v67i1.867

Vorster, W.S., 1987, 'Op weg na 'n post-kritiese Nuwe-Testamentiese wetenskap', HTS Teologiese Studies/Theological Studies 43, 374-394.

Wolter, M., 2001, 'Die ethische Identität christlicher Gemeinden in neutestamentlicher Zeit', in W. Härle \& R. Preul (Hrsg.), Woran orientiert sich Ethik?, pp. 61-90, Elwert Verlag, Marburg. 